\title{
INCIDENCE OF IDIOPATHIC ACQUIRED OBSTRUCTIONS IN THE LACRIMAL DRAINAGE APPARATUS*
}

\author{
BY \\ R. DALGLEISH \\ Manchester Royal Eye Hospital
}

IN the vast majority of cases the aetiology of an acquired obstruction in the lacrimal drainage apparatus remains obscure. Overt infection is a common associate, especially with obstructions involving the naso-lacrimal duct. It is still not clear whether the infection is causal or sequential to the obstruction, or whether these two factors are simply part of a wider diathesis. At the present time, this group of acquired obstructions must be regarded as idiopathic.

From a perusal of the literature, it would appear that no information is available concerning the absolute incidence of these obstructions. Related work concerns the percentage of ophthalmic patients who attend with epiphora; this appears to have varied from 2.7 to 3.7 per cent. in different centres in Great Britain at different times (Traquair, 1941; Foster, 1956). Similarly, the ratio of females to males attending ophthalmic clinics with dacrocystitis is about 5:1 (Traquair, 1941); many authors claim that this ratio applies to the incidence of dacryocystitis in the population as a whole (Duke-Elder, 1952). Stallard (1958) states that naso-lacrimal duct obstruction is four times as common in females as in males, and that the left side is more commonly affected than the right. It would appear that much of this information has been derived from the relative incidence of males and females attending ophthalmic clinics with these complaints. In this respect it must be pointed out that, excluding industrial accidents, adult females normally outnumber adult males at the Outpatient Clinics of the Manchester Royal Eye Hospital, and that this probably applies to other centres in this country. Many factors contribute to the preponderance of females at these clinics, and it does not always receive sufficient attention when assessments are made of the relative incidence of ophthalmic conditions in the two sexes from statistics so derived.

It is the purpose of this paper to present information concerning the near-absolute incidence of idiopathic acquired obstruction in the lacrimal drainage apparatus, and the true relative incidence of this condition in males compared with females.

\section{Method}

All patients admitted to the Manchester Royal Eye Hospital for "cold" intra-ocular surgery undergo routine syringing of the lacrimal drainage apparatus on both sides. Since 1959 the syringings have been carried out by medical staff, and the survey has been confined to these cases. Most of those included in this series were admitted for cataract surgery, or surgery for chronic simple glaucoma. There was no significant difference in the incidence of obstruction in the lacrimal drainage apparatus in the "cataract group" as compared with the "glaucoma group", and it is assumed that neither of these conditions bears any direct relationship to the incidence of the obstructions. Five cases were excluded from the series as there appeared to be an obvious external cause for the obstruction; two of these were post-traumatic in origin, and the remaining three had received radio-therapy to the region of the inner canthus. This left 3,487 cases in which the required information had been recorded. 
In the following Tables and discussion, Patent means that a cannula was passed into the lower canaliculus, and that by this means saline was syringed through the lacrimal drainage apparatus into the nasal cavity. Obstructed means either that the lower canaliculus could not be entered with a cannula, or that, the cannula having entered the canaliculus, saline could not be syringed through to the nose. The precise situation of the obstruction is not taken into account in this paper.

In the following discussion, not significant means that the observed difference in two proportions did not exceed twice the standard error.

In Table I the patients are grouped according to age and sex, and it is recorded whether the lacrimal drainage apparatus is patent on both sides, or obstructed on one or both sides. A further analysis of the "obstructed" cases shows whether the obstruction affected the right side, the left side, or both sides.

If one wishes to consider the overall incidence of obstruction in males as compared with females, it will be seen that satisfactory numerical samples are available in the age groups 50-59, 60-69, 70-79, and 80-89 years (Table I, Part I).

TABLE I

PART I. FINDINGS IN 3,487 CASES, BY AGE AND SEX

\begin{tabular}{|c|c|c|c|c|c|c|c|c|c|c|c|c|}
\hline \multirow{3}{*}{$\underset{\text { (yrs) }}{\text { Age Group }}$} & \multirow{3}{*}{ Sex } & \multirow{3}{*}{$\begin{array}{c}\text { Number } \\
\text { of } \\
\text { Patients }\end{array}$} & \multirow{2}{*}{\multicolumn{2}{|c|}{$\begin{array}{c}\text { Patent } \\
\text { on Both } \\
\text { Sides }\end{array}$}} & \multirow{2}{*}{\multicolumn{2}{|c|}{$\begin{array}{l}\text { Obstructed } \\
\text { on One or } \\
\text { Both Sides }\end{array}$}} & \multicolumn{6}{|c|}{ Analysis of Obstructed Cases } \\
\hline & & & & & & & \multicolumn{2}{|c|}{ Right only } & \multicolumn{2}{|c|}{ Left only } & \multicolumn{2}{|c|}{ Right and Left } \\
\hline & & & No. & $\begin{array}{l}\text { Per } \\
\text { cent. }\end{array}$ & No. & $\begin{array}{l}\text { Per } \\
\text { cent. }\end{array}$ & No. & $\begin{array}{l}\text { Per } \\
\text { cent. }\end{array}$ & No. & $\begin{array}{l}\text { Per } \\
\text { cent. }\end{array}$ & No. & $\begin{array}{l}\text { Per } \\
\text { cent. }\end{array}$ \\
\hline $\begin{array}{l}29 \text { and } \\
\text { Under }\end{array}$ & $\begin{array}{l}\text { Male } \\
\text { Female }\end{array}$ & $\begin{array}{r}17 \\
5\end{array}$ & $\begin{array}{r}17 \\
5\end{array}$ & $\begin{array}{l}100 \\
100\end{array}$ & $=$ & 二 & - & 二 & 二 & 二 & 二 & 二 \\
\hline $30-39$ & $\begin{array}{l}\text { Male } \\
\text { Female }\end{array}$ & $\begin{array}{l}44 \\
21\end{array}$ & $\begin{array}{l}43 \\
21\end{array}$ & $\begin{array}{r}98 \\
100\end{array}$ & 1 & -2 & 二 & 二 & 1 & $2^{2}$ & 二 & 二 \\
\hline $40-49$ & $\begin{array}{l}\text { Male } \\
\text { Female }\end{array}$ & $\begin{array}{l}69 \\
43\end{array}$ & $\begin{array}{l}61 \\
41\end{array}$ & $\begin{array}{l}88 \\
95\end{array}$ & $\begin{array}{l}8 \\
2\end{array}$ & $\begin{array}{r}12 \\
5\end{array}$ & - & 4 & $\begin{array}{l}5 \\
1\end{array}$ & $\begin{array}{l}7 \\
2\end{array}$ & -1 & $\overline{2}$ \\
\hline $50-59$ & $\begin{array}{l}\text { Male } \\
\text { Female }\end{array}$ & $\begin{array}{l}199 \\
236\end{array}$ & $\begin{array}{l}178 \\
210\end{array}$ & $\begin{array}{l}89 \\
89\end{array}$ & $\begin{array}{l}21 \\
26\end{array}$ & $\begin{array}{l}11 \\
11\end{array}$ & $\begin{array}{r}8 \\
10\end{array}$ & $\begin{array}{l}4 \\
4\end{array}$ & $\begin{array}{l}6 \\
6\end{array}$ & $\begin{array}{l}3 \\
3\end{array}$ & $\begin{array}{r}7 \\
10 .\end{array}$ & $\begin{array}{l}4 \\
4\end{array}$ \\
\hline $60-69$ & $\begin{array}{l}\text { Male } \\
\text { Female }\end{array}$ & $\begin{array}{l}350 \\
604\end{array}$ & $\begin{array}{l}278 \\
495\end{array}$ & $\begin{array}{l}79 \\
82\end{array}$ & $\begin{array}{r}72 \\
109\end{array}$ & $\begin{array}{l}21 \\
18\end{array}$ & $\begin{array}{l}23 \\
34\end{array}$ & $\begin{array}{l}7 \\
6\end{array}$ & $\begin{array}{l}28 \\
37\end{array}$ & $\begin{array}{l}8 \\
6\end{array}$ & $\begin{array}{l}21 \\
38\end{array}$ & $\begin{array}{l}6 \\
6\end{array}$ \\
\hline 70-79 & $\begin{array}{l}\text { Male } \\
\text { Female }\end{array}$ & $\begin{array}{l}442 \\
955\end{array}$ & $\begin{array}{l}318 \\
720\end{array}$ & $\begin{array}{l}72 \\
75\end{array}$ & $\begin{array}{l}124 \\
235\end{array}$ & $\begin{array}{l}28 \\
25\end{array}$ & $\begin{array}{l}41 \\
75\end{array}$ & $\begin{array}{l}9 \\
8\end{array}$ & $\begin{array}{l}32 \\
66\end{array}$ & $\begin{array}{l}7 \\
7\end{array}$ & $\begin{array}{l}51 \\
94\end{array}$ & $\begin{array}{l}12 \\
10\end{array}$ \\
\hline $80-89$ & $\begin{array}{l}\text { Male } \\
\text { Female }\end{array}$ & $\begin{array}{l}145 \\
331\end{array}$ & $\begin{array}{r}93 \\
226\end{array}$ & $\begin{array}{l}64 \\
68\end{array}$ & $\begin{array}{r}52 \\
105\end{array}$ & $\begin{array}{l}36 \\
32\end{array}$ & $\begin{array}{l}16 \\
16\end{array}$ & 11 & $\begin{array}{l}14 \\
31\end{array}$ & $\begin{array}{r}10 \\
9\end{array}$ & $\begin{array}{l}22 \\
58\end{array}$ & $\begin{array}{l}15 \\
18\end{array}$ \\
\hline $\begin{array}{l}90 \text { and } \\
\text { Over }\end{array}$ & $\begin{array}{l}\text { Male } \\
\text { Female }\end{array}$ & $\begin{array}{l}10 \\
16\end{array}$ & $\begin{array}{r}6 \\
12\end{array}$ & $\begin{array}{l}60 \\
75\end{array}$ & $\begin{array}{l}4 \\
4\end{array}$ & $\begin{array}{l}40 \\
25\end{array}$ & - & $\overline{19}$ & -2 & $\frac{20}{-}$ & $\begin{array}{l}2 \\
1\end{array}$ & $\begin{array}{r}20 \\
6\end{array}$ \\
\hline \multicolumn{13}{|c|}{ PART II } \\
\hline All Ages & $\begin{array}{l}\text { Male } \\
\text { Female }\end{array}$ & $\begin{array}{l}1,276 \\
2,211\end{array}$ & $\begin{array}{r}994 \\
1,730\end{array}$ & $\begin{array}{l}78 \\
78\end{array}$ & $\begin{array}{l}282 \\
481\end{array}$ & $\begin{array}{l}22 \\
22\end{array}$ & $\begin{array}{r}91 \\
138\end{array}$ & $\begin{array}{l}7 \\
6\end{array}$ & $\begin{array}{r}88 \\
141\end{array}$ & $\begin{array}{l}7 \\
6\end{array}$ & $\begin{array}{l}103 \\
202\end{array}$ & $\begin{array}{l}8 \\
9\end{array}$ \\
\hline \multicolumn{13}{|c|}{ PART III } \\
\hline All Ages & $\begin{array}{l}\text { Both } \\
\text { Sexes }\end{array}$ & 3,487 & 2,724 & 78 & 763 & 22 & 229 & 7 & 229 & 7 & 305 & 9 \\
\hline
\end{tabular}


In each of these four groups the incidence of obstruction is more or less equal in the two sexes (Table II).

TABLE II

INCIDENCE OF OBSTRUCTION BY AGE AND SEX

\begin{tabular}{c|c|c}
\hline \multirow{2}{*}{ Age Group (yrs) } & \multicolumn{2}{|c}{ Incidence of Obstruction (per cent.) } \\
\cline { 2 - 3 } & Male & Female \\
\hline $50-59$ & 11 & 11 \\
\hline $60-69$ & 21 & 18 \\
\hline $70-79$ & 28 & 25 \\
\hline $80-89$ & 36 & 32 \\
\hline
\end{tabular}

From 60-89 years the incidence is in fact slightly higher in males, but this is not significant. Attention is drawn to the linear increase in the incidence of obstruction in both sexes from the 50-59 to the 80-89 year age group (Figure). It is reasonable to assume that these curves can be extended in both directions (dotted lines in Figure). It will be seen that the extended curves intersect the abscissa at about 35 years for males, and at about 39 years for females.

This would indicate that these are the earliest ages at which an acquired ob-

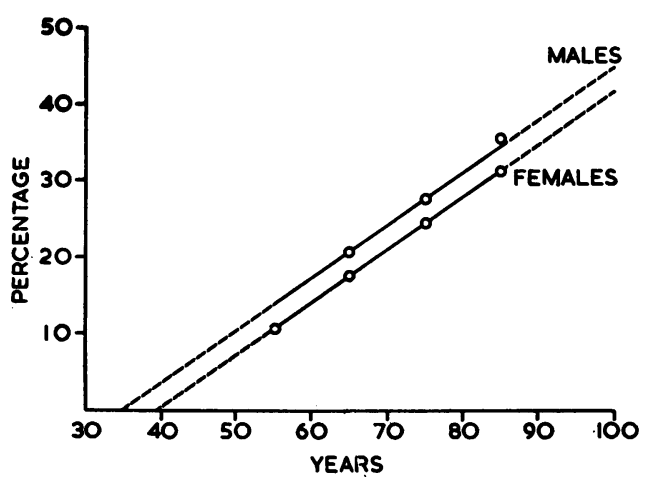

FIGURE.-Incidence of obstruction, by age and sex. struction is likely to develop in the two sexes respectively, and is strongly supported by the information available from the group of 87 patients under the age of 40 years (Table I, Part I), in which only one obstruction (unilateral) was detected. It is suggested that this graph offers an accurate means of assessing the expected incidence of acquired obstruction in the lacrimal drainage apparatus for any age group.

\section{Analysis of the Cases with Obstruction on One Side or Both}

(A) There is no significant difference in the incidence of right obstructions as compared with left obstructions. This is well illustrated if we consider the group as a whole (3,487 patients); there were 229 right obstructions and 229 left obstructions, an incidence of 7 per cent. for each side (see Table I, Part III). The incidence is still equal if we consider males and females separately (see Table I, Part II), and the comparative incidence is very nearly equal (males 7 per cent., females 6 per cent.).

(B) In comparing the incidence of unilateral obstructions (right or left) with bilateral obstructions, satisfactory numerical samples are available in the four age groups between 50 and 89 years (Table III, overleaf). 
In each of these four age groups, the incidence of bilateral cases is far in excess of the incidence one would expect from a random coupling of unilateral obstructions. In addition, the increase in the incidence of bilateral cases as the age of the group increases is significantly greater than that of unilateral obstructions (Table III).

TABLE III

SITE OF OBSTRUCTION BY AGE AND SEX

\begin{tabular}{|c|c|c|c|c|}
\hline \multirow{2}{*}{ Age Group (yrs) } & \multirow{2}{*}{ Sex } & \multicolumn{3}{|c|}{ Obstruction (per cent.) } \\
\hline & & Right only & Left only & Right and Left \\
\hline $50-59$ & $\begin{array}{l}\text { Male } \\
\text { Female }\end{array}$ & $\begin{array}{l}4 \\
4\end{array}$ & $\begin{array}{l}3 \\
3\end{array}$ & $\begin{array}{l}4 \\
4\end{array}$ \\
\hline $60-69$ & $\begin{array}{l}\text { Male } \\
\text { Female }\end{array}$ & $\begin{array}{l}7 \\
6\end{array}$ & $\begin{array}{l}8 \\
6\end{array}$ & $\begin{array}{l}6 \\
6\end{array}$ \\
\hline $70-79$ & $\begin{array}{l}\text { Male } \\
\text { Female }\end{array}$ & $\begin{array}{l}9 \\
8\end{array}$ & $\begin{array}{l}7 \\
7\end{array}$ & $\begin{array}{l}12 \\
10\end{array}$ \\
\hline $80-89$ & $\begin{array}{l}\text { Male } \\
\text { Female }\end{array}$ & $\begin{array}{r}11 \\
5\end{array}$ & $\begin{array}{r}10 \\
9\end{array}$ & $\begin{array}{l}15 \\
18\end{array}$ \\
\hline
\end{tabular}

If we postulate that unilateral and bilateral cases have a common aetiology, then these findings would appear to indicate that the factors predisposing to the development of an obstruction tend to have a bilateral effect, and that the expression of this bilateral effect increases as age advances. On the other hand, there may be a more fundamental difference between unilateral and bilateral obstructions which could account for these findings. This latter concept is supported by clinical and surgical differentiations referred to in a previous communication (Dalgleish, 1963).

\section{Summary}

The incidence of idiopathic acquired obstructions in the lacrimal drainage apparatus has been assessed in a group of 3,487 patients. It is suggested that this group of patients may be regarded as a near-random sample of the population of this region.

The overall incidence of obstructions on one or both sides, in males as compared with females, is more or less equal in any age group. There is a linear increase in the overall incidence of these obstructions as age advances, and it is suggested that the Figure offers an accurate means of assessing the expected incidence of idiopathic acquired obstructions for any age group. It is shown that 35-40 years is the earliest expected age at onset of an obstruction of this type.

There is no significant difference in the incidence of right obstructions compared with left obstructions.

The incidence of bilateral obstructions is compared with the incidence of unilateral obstructions, and the inter-relationship of these two groups is discussed.

I gratefully acknowledge the assistance of Dr. E. J. Naylor with the tests of statistical significance. I wish to thank my colleagues at the Manchester Royal Eye Hospital for permission to use their case records.

\section{REFERENCES}

DAlgleish, R. (1963). Trans. ophthal. Soc. U.K., 83, 437.

DUKE-ElDER, S. (1952). "Text-book of Ophthalmology", vol. 5, p. 5300. Kimpton, London.

FOSTER, J. (1956). Ann. roy. Coll. Surg. Engl., 18, 143.

STAllaRD, H. B. (1958). "Eye Surgery”, 3rd ed., p. 279. Wright, Bristol.

Traquair, H. M. (1941). Arch. Ophthal. (Chicago), 26, 165. 